\title{
New Ideas on Teaching Reform of Visual Communication Design in Colleges and Universities
}

\author{
Guangping Gou \\ Art college of xi'an University 710065 \\ Keywords: Colleges and Universities; Visual Communication Design; Teaching Reform; New Ideas
}

\begin{abstract}
With the rapid development of social economy in China, education is also evolving. At present, many colleges and universities have been a decent teaching results in the visual communication design. At the same time, with the development of education, visual communication design is also progressing and more and more new teaching ideas have emerged, which is directly related to the overall teaching effect. At present, it has become the most important research topic in a lot of colleges and universities that how to reform visual communication design combined with education situation, innovate teaching mode and curriculum and focus on cultivating students' sense of innovation and learning ability. This paper will analyze the current situation of the visual communication design of domestic colleges and universities and discuss the teaching reform, hoping to provide some reference for promoting Chinese visual communication design teaching quality.
\end{abstract}

\section{Introduction}

In recent years, Chinese social economy has a rapid development and various professional talents are the driving force of social development. With the progress of society, the demand for professionals is also growing, especially people who has the ability to innovate. According to the statistics of the Ministry of Education, at present, there are more than 1,000 colleges and universities that have opened the course of visual communication design, and the number of undergraduates and college students in general is more than 100,000. Design major can not only need designers have the ability to design software, but also have a wealth of imagination, innovation, aesthetic ability and design standards. The main educational place of cultivating designers in our country are colleges and universities, which provide students with the most comprehensive education and cultivate students' design ability, imagination, innovation ability and aesthetic ability. Therefore, colleges and universities cultivate high quality designers for society. As the scale of education is still in the rapid expansion, it is still a important and urgent topic to reform curriculum and teaching model for colleges and universities. Therefore, colleges and universities need to reform the traditional teaching model of visual communication design to enhance the teaching philosophy fitting the needs of the times, fully combined with professional theory and social practice and integrated the effective resources. Finally, visual communication design can be more in line with the direction of social development and get better teaching management to meet the needs of Chinese future development.

\section{The Review and Thinking of Visual Communication Design Teaching}

For now, the teaching methods, models and ideas of professional courses are often not in line with the actual situation of society in most of the domestic colleges and universities. First, most colleges and universities still use the traditional course content when they set up courses. The school's professional education and social needs of professionals have a more obvious contradiction because the school's professional content is monotonous. The first modern design education course is in the eighty times of the twentieth century in China. Most of teaching models learn and introduce from the western developed countries as the domestic foundation in this area is relatively weak. The designs of professional education in domestic colleges and universities mostly use the teaching model which western developed countries have been put into use and get a certain result whether it is art education, decorative education, applied art education or visual communication design 
education. The teaching model design does not meet the actual situation of China, so it not only lacks innovation, but also not achieve a good results. These problems are the prevailing problems of most professional education in Chinese colleges and universities. We need to reflect and find ways to solve these problems in a timely manner, so as to provide an important guarantee for the quality and effect of visual communication design.

\section{Current Problems of Visual Communication Design Education}

Teaching Model Does Not Meet the Development Needs of Design Industry. The first achievement of domestic colleges and universities on the design is the late of last century. At that time, people only had a clearer understanding on design of the teaching philosophy, but the results achieved at then is not perfect. With the rapid social development, the results achieved at that time can not always fit the needs of social development, and after that most of the modern design education courses are learning from educational experience of western developed countries. This kind of reference situation can not let the design of our country's professional education curriculum meet the actual situation of social needs and it not combine with the requirements of social design professionals, lacking innovation and practice. This is one of the most important problems in the development of visual communication design education in China at present.

Teaching Content and Curriculum Settings Are Unreasonable. Most of the domestic colleges and universities are selected the traditional teacher teaching mode in the professional courses, mainly to impart theoretical knowledge. However, such a teaching model does not apply to visual communication design and monotonous theoretical knowledge can not meet the requirement to let students learn a comprehensive design concept. The teaching mode of teacher mainly focuses on the theoretical knowledge of the book. It will let the students gradually lose the enthusiasm of learning because of the tedious teaching mode. At the same time, it ignores the necessary computer application operation ability for design. Nowadays, design enterprises need innovative talents who not only have marketing idea and the necessary computer application skills, but also must have imagination and innovation. However, the traditional teacher teaching mode has long been unable to meet the needs of the market, and students do not meet the requirements of the design enterprises. Finally, students have difficult to find jobs after graduation and enterprises can not find suitable employees.

In addition, the irrational teaching curriculum is also one of the important reasons that visual communication design students can not meet the requirements of social development. Most of the teaching content which not update with the times used in visual communication design professional courses has been out of the current social development needs, which lead to most of the knowledge that teachers transfer to the students in class is not fit the current requirements. This kind of education is difficult to cultivate compound talents that social and enterprises need. The knowledge that students learn from class can not fit the actual situation, so students can not keep up with the pace of social development after graduation and can not find a good job.

\section{New Ideas of Setting up Curriculum of Visual Communication Design}

Visual Communication Design courses include theoretical knowledge and practical exploration. The purpose of reforming visual communication design teaching is to let curriculum system show the new ideas of professional construction, reflect the characteristics of the design and cultivate professional design talent combined with the needs of social development.

Focus on Teaching Practicality. When setting up a visual communication design course, it is necessary to combine scientific research and design practice into the teaching content. The professional teaching results will be promoted and popularized $\mathrm{n}$ the class, so as to be able to play its greatest value. In addition, teaching should use a variety of ways to achieve a good effect of education, so that the curriculum system is more abundant. And colleges and universities should also cooperate with design enterprises to promote the exchange of academic and production. On the one hand, it can let teachers understand the needs of the market and social development, on the 
other hand, it can promote the results of education to the market, which can take full use of the advantages of business cooperation and highlight their own characteristics. Detailed practice shows as the following. First, according to the develop situation of industry and the needs of social development, combined with the actual needs of the design profession, apply the achievements of scientific research and design results for curriculum content. For example, combine the basic photography curriculum with the sketch professional course, so that students have plenty of time to study their expertise. Practical activities can not only improve the artistic quality of students, but also students are able to learn more visual design expertise. Second, Colleges and universities can also provide creative exhibition for graduates, which not only allows graduates to get more independent thinking, independent design and independent hands-on artistic creation opportunities, but also allows students that still study in school to learn the design ideas from their senior schoolmates. The Art Design Center provides these students with a team of professional teachers who bring their own works to participate in the competition, accumulate experience and improve their appreciation when observing others' works.

Optimize and Integrate Curriculum Resources. Integrate scientific research activities organically into the course content to establish a more perfect curriculum system. At the same time, school selects the appropriate candidates in the teacher team to take charge of the curriculum management system and clear the responsibilities of the job. Detailed practice shows as the following. First, take the employment of students as the main purpose, according to the needs of social development in a timely manner to improve the education focus of curriculum system, adjust the direction of training, cultivate innovative talents, professional and practical personnel and compound talents. According to the development of professional design to set up key courses and according to the actual needs of the market to develop the teaching purposes of professional courses. To ensure that the curriculum system is adjusted and improved constantly according to the market changing and take the needs of social development as a standard to train talent. Second, set up curriculum according to scientific research requirements and establish key curriculum system, using scientific research methods to enhance the teaching level. Combine the basic theoretical knowledge, innovative design and professional skills training together to open a variety of basic theory courses and professional courses, so as to develop students' professional core competencies.

\section{New Ideas of Visual Communication Design Teaching Model}

Change Traditional Education Thought and Strengthen Teaching Method Innovation. Design professional educators need to combine the professional theoretical knowledge and design practice to enhance the professionalism of students and develop students' professional skills. Take the needs of social development as a reference to select the appropriate way of education and maintain the correct concept of education, continuous integrating all teaching resources and organically combining artistic creativity and professional design. Specific methods show as the following. First, continuously optimized and enrich teaching resources rather than use traditional teacher teaching mode. Teachers should not be confined to the knowledge of the book but use modern multimedia equipment and network information technology for multimedia teaching. This will not only enable students to learn the latest ideas, art forms, innovation awareness and invention, greatly broaden the horizons of students, but also to expand the knowledge involved by design professional teaching. Through a variety of media to open the students learning ideas and develop the ability to innovate and imagination. Second, use a variety of different teaching forms to improve the teaching methods, so that it can effectively complete some shortcomings of the traditional teaching model, which not only can arouse students' enthusiasm and interest in learning, but also cultivate the ability to learn independently.

Give Full Play to the Student's Main Role in the Teaching Process. In the course of teaching, teachers need to pay attention to students' experience and feelings in the learning process, and take this as a purpose to strengthen the teaching innovation. Specific methods show as the following. First, use segmental pedagogy to enhance communication and interaction between students. After the students have mastered the professional knowledge of the design profession, teachers should 
bring the students more creative, novel and content form and let students form groups to discuss and research on their own. Finally, teachers and students exchange together, which not only to stimulate the enthusiasm of students, but also to cultivate students the habit of independent research. Second, teachers teach step by step and use theoretical knowledge flexibly. Students practice themselves and teachers counsel in the whole process. At the end, discuss and exchange with students and then let students sum up and evaluate.

\section{Conclusion}

As mentioned above, with the rapid development of Chinese social and economic construction, all areas of society are thriving to all professional talents, especially the increasing demand for professional designers. And colleges and universities are the most common training place for design professionals in China, so the university's visual communication design professional education team shoulders the task of cultivating high-quality design professionals for the society. In the teaching reform of visual communication design in colleges and universities, curriculum setting up and the reform of teaching mode are the most important. Only improve effectively the curriculum and teaching mode of visual communication design can make the course content more fit the development and requirements of the times. Fully integrate with the professional theory and social practice of the course and integrate all resources to strengthen the resource allocation of teaching, so as to adjust the traditional teaching model of visual communication design curriculum and cultivate design professionals to meet the needs of society. Finally, cultivate high-quality personnel for society and promote the further development of Chinese social and economic construction.

\section{Acknowledgements}

Project Name: The Teaching Reform Of Advertising Design Course Practical Application Under The Innovative Entrepreneurship Education Background.

Project Number: JG2017078

\section{Reference}

[1] Q.X. Chen and W.L. Tao. Innovation and Practice of Humanistic Value in the Teaching of Visual Communication Design in Colleges and Universities - Taking Traditional Festivals as an Example [J]. China Packaging Industry, 2014, 18: 103-104.

[2] B. Shu. A Discussion on Teaching Reform of Basic Courses in Visual Communication Design Taking Hohhot Institute for Nationalities as an Example [J]. Inner Mongolia Education (Vocational Education Edition), 2014, 12: 47-48.

[3] X. Qiu and Y. Wang. Discussion of the Local College Visual Communication Design Professional Three - Dimensional Teaching Model Reform Based on the Transformation Background [J]. Journal of Hubei Normal University (Philosophy and Social Sciences), 2016, 04: 103-105.

[4] Y.N. Chen and J.S. Zhang. Visual Communication Design, Environmental Design Professional Practice Teaching System Reform Research [J]. Journal of Lanzhou Education College, 2013, 01: $133-134+150$.

[5] J.K. Zhang. Research on the Teaching Reform of Visual Sketch Teaching - Based on Graphic Creativity Design Sketch Teaching Research [J]. Journal of Jilin Radio \& Television University, 2013, 10: 66-67.

[6] M.M. Tan. The Practice and Practice of Practical Teaching Reform of Visual Communication Art Design Specialty - Taking Hubei Vocational and Technical College of Transportation as an Example [J]. Fine Art, 2016, 01: 140-141.

[7]S.J. Cang and J. Wang. Ideas on Teaching Reform of Art Design in Colleges and Universities [J]. Journal of Shanxi Normal University (Social Science Edition), 2014, S3: 162-164.

[8] Y. Ruan. Reform of Teaching Methods for Visual Communication Design in Private Colleges - 
Taking Matsuda Academy of Guangzhou University as an example [J]. Art Education Research, 2014, 09: 139.

[9] T.J. Li. The Role of Font Design in the Teaching of Visual Communication in Colleges and Universities [J]. Journal of Chifeng University (Natural Science Edition), 2016, 08: 259-261.

[10]D.Y. Yi. A Study into the Teaching Reform of Visual Communication Design in Colleges and Universities - Comments on Jin Taiqiang's "Visual Communication Design Practice" [J]. News and Writing, 2016, 09: 133.

[11] Y.J. Liu, P. Chen and Z. Su. On the Characteristics of Teaching Reform in Visual Communication Design Specialty of Private Colleges in Taiwan - Taking Shude University of Science and Technology as an Example [J / OL]. Electronic Production, 2013(22).

[12]L. Lu. Teaching Reform and Exploration of Graphic Design Software Course - Taking Visual Direction as an Example [J]. Art and Design (theory), 2013, 04: 169-170. 